\title{
The Photometric Autotitration of free Fatty Acids ${ }^{1}$ )
}

\author{
By J. KeUL, N. LINNET ${ }^{2}$ ) and E. ESCHENBRUCH
}

From the Department of Internal Medicine of the University of Freiburg|Br., Germany

(Eingegangen am 22. März 1968)

\begin{abstract}
A description is given of a new method for determining free fatty acids in blood plasma. The free fatty acids are extracted from the plasma, transferred to heptane and washed with $\mathrm{H}_{2} \mathrm{SO}_{4}(0.01 \mathrm{~N})$. The earlier two-phase tritration procedure is now performed in a oze-phase medium by means of an autoburette using tetrabutylammoniumhydrcxide. A curve, simultaneously recorded by means of a compensation recorder, allows for an accurate determination of the transition point of the titration, and accurate and reproducible measuring values can therefore be obtained. An unambiguous determination of small arterio-venous differences is likewise possible by this method.
\end{abstract}

Es wird eine neue Methode zur Bestimmung von freien Fettsäuren im Blutplasma beschrieben. Die freien Fettsäuren werden aus dem Plasma extrahiert, in Heptan überführt und mit $\mathrm{H}_{2} \mathrm{SO}_{4}(0,01 \mathrm{~N})$ gewaschen. Statt der bisherigen Titration im $\mathrm{Z}$ wei-Phasen-Medium wird in einem einphasischen Medium mit einer Autobürette unter Verwendung von Tetrabutylammoniumhydroxid titriert; eine gleichzeitig von einem Kompensationsschreiber aufgezeichnete Kurve läßt eine genaue Bestimmung des Titrationsumschlagpunktes zu, und somit können exakte, reproduzierbare Meßwerte erzielt werden. Kleine arteriovenöse Differenzen lassen sich mit dieser Methode noch eindeutig bestimmen.

Ever since Dole (1) and Gordon and Cherkes (2) indicated new methods for the quantitative determination of free fatty acids in blood plasma, various teams of scientists have devoted their studies to the detection of free fatty acids in fluids and tissue, and in the course of their experiments repeatedly modified the methods to suit their particular requirements. The many modifications of the original procedure for determining free fatty acids show only too clearly that no method so far developed satisfies the requirements.

A critical comparison of several fairly closely related methods, as undertaken by Nerson (3), indicated that the procedure advocated by DOLE - viz., an extraction process for transferring the free fatty acids of the plasma to an organic fluid - was of fundamental importance in making quantitative analyses. Apparently (3), not only acids like lactic acid and acetic, but also phosphatides, gave free fatty acid values that were too high when determined according to DOLE (1). More accurate results can be obtained through washing with $\mathrm{H}_{2} \mathrm{SO}_{4}$. This is due to a better separation of isopropanol/water and heptane (3). Since the heptane phase will no longer contain water/ isopropanol with water-soluble, base-binding substances, the free fatty acids will be included only in the nonaqueous medium.

Such titrations carried out in a non-aqueous environment with aqueous $\mathrm{NaOH}$ were not satisfactory, as the production of two phases influenced both the accuracy and the reproducibility.

In 1965 Kelley (4) first indicated a titration procedure for determining free fatty acids, in which $\mathrm{TBAH}^{3}$ ), which is soluble in heptane and isopropanol, was used as titrant. As indicator, he used phenol red dissolved in ethanol.

The present work concerns a determination of free fatty acids based on the experience so far gathered (1, 3-7).

1) Supported by a grant from the Deutsche Forschungsgemeinschaft (German Research Association) and the Kuratorium für Sportmedizin (Cologne).

2) Radiometer A/S, Copenhagen/Denmark.

3) Abbreviation: $\mathrm{TBAH}=$ tetrabutylammoniumhydroxide.
The free fatty acids are transferred to a heptane phase and titrated with TBAH, using 1-(2-hydroxy-benzene) azo-2-naphthol as the indicator. The titration is performed automatically by means of the Radiometer Titrigraph and is continuously recorded.

\section{Method}

Blood Sampling

A minimum of $3 \mathrm{~m} l$ whole blood is drawn into a heparinized syringe $\left.{ }^{4}\right)$. Once filled, the syringe is sealed and vigorously shaken several times to ensure complete heparinization, and it is then set aside in a $10 \mathrm{~m} l$ centrifuge tube containing ice water. Afterwards, the blood is centrifuged for 10 to $15 \mathrm{~min}$. at $2000 \mathrm{r}$. p. m., and the " plasma is then removed.

Following this, the free fatty acid content must either be deter mined immediately, or the plasma must be stored at $-30^{\circ} \mathrm{C}$.

Preparing the Blood Plasma

The task of preparing a sample for titration can be divided into an extraction procedure $(1,5)$ and a washing procedure.

\section{Laboratory equipment}

$25 \mathrm{~m} /$ test tubes with tapered glass stoppers

$10 \mathrm{~m} l$ centrifuge tubes

Beakers $(50-150 \mathrm{~m} /)$

Graduated cylinders $(100,500 \mathrm{~m} l)$

$100 \mathrm{~m} /$ volumetric flasks with tightly-fitting tapered glass stoppers for standard solutions

$500 \mathrm{~m} /$ volumetric flasks with tightly-fitting tapereed glass stoppers for extraction mixture

$100 \mu l, 1000 \mu l, 2000 \mu l$ micro-pipettes; also $1 \mathrm{~m} /, 2 \mathrm{~m} /, 3 \mathrm{~m} /$, $4 \mathrm{~m} l, 5 \mathrm{~m} l, 10 \mathrm{~m} l$ and $15 \mathrm{~m} l$ pipettes.

\section{Reagents}

a) Extraction mixture:

40 parts isopropanol

10 parts heptane

1 part $\mathrm{H}_{2} \mathrm{SO}_{4}, 1 \mathrm{~N}$.

The extraction mixture must be protected from atmospheric carbon-dioxide and from evaporation (which occurs at different

4) In agreement with the report' of FreDERICKSON and GoRDON (8), we did not find any lipolysis in vitro under the influence of heparin. Duplicate analyses, in which blood plasma was obtained after admixture of heparin or sodium citrate, differed by less than $\pm 2 \%$. 
speed for the different components) by keeping it in a tightlystoppered bottle.

b) Washing solution:

$\mathrm{H}_{2} \mathrm{SO}_{4}, 0.01 \mathrm{~N}$

$1 \mathrm{~m} / \mathrm{H}_{2} \mathrm{SO}_{4}, 1.0 \mathrm{~N}$ is poured into a $100 \mathrm{~m} /$ volumetric flask and diluted with twicedistilled water to make $100 \mathrm{~m} /$ solution.

c) Standard solutions:

Palmitic acid stock solution: (24 mM):

$0.6154 \mathrm{~g}$ palmitic acid dissolved in $1000 \mathrm{~m} /$ heptane.

Palmitic acid "Standard A" (1.2 mM):

$5 \mathrm{~m} /$ "stock solution" arc diluted with heptane to make $100 \mathrm{~m} /$.

Palmitic acid "Standard B" $(0.3 \mathrm{mM})$ :

$25 \mathrm{~m} /$ "Standard A" are diluted with heptane to make $100 \mathrm{~m} /$.

d) Titrant:

$0,004 \mathrm{M}$ tetrabutylammoniumhydroxide in isopropanol/methanol.

e) Indicator:

$0.1 \%$ phenol red in cthanol.

Great care must be exercised in handling the palmitic acid stadards. The storage flasks must always be tightly stoppered. After a sample is drawn, the stopper must immediately be reinserted into the flask.

\section{Extraction procedure}

$5 \mathrm{~m} /$ extraction solution $+1 \mathrm{~m} /$ plasma are pipetted into a $25 \mathrm{~m} /$ test tube with tapered glass stopper and then shaken vigorously so that the albumin is precipitated and drops to the bottom of the test tube.

The sample is left standing for $10 \mathrm{~min}$, and $3 \mathrm{~m} /$ heptane and $3 \mathrm{~m} /$ twice-distilled water are then added, following which the sample is shaken vigorously for $1 \mathrm{~min}$. and again set aside for $5 \mathrm{~min}$.

The extraction mixture will now separate into two phases: at the top into a (at first) small phase of heptane, which, however, rapidly grows to more than $4 \mathrm{~m} l$; at the bottom into a water/ isopropanol phase containing flocculated albumin. The interface between the phases becomes sharply defined after a few minutes, so that the heptane phase at the top is easily removed.

\section{Wasbing procedure}

$3 \mathrm{~m} / 0.01 \mathrm{~N} \mathrm{H}_{2} \mathrm{SO}_{4}$ and $3 \mathrm{~m} /$ of the heptane phase from the extraction procedure are pipetted into a $10 \mathrm{~m} /$ centrifuge tube furnished with a tapered stopper. The mixture is then shaken vigorously for $1 \mathrm{~min}$. and left standing for another $10 \mathrm{~min}$. The mixture is now placed in a ccntrifuge and centrifuged for $10 \mathrm{~min}$. at 2000 r. p. m.

Afterwards the mixture will again be separated into two phases of which the upper one consists of heptane $(>2 \mathrm{~m} /)$ with the free fatty acids.

\section{Titrating, Recording and Computing}

For use in titration, $2 \mathrm{ml}$ of the washed heptane phase are transferred to a titration beaker together with $15 \mathrm{~m} l$ isopropanol and $100 \mu /$ indicator $\left.{ }^{5}\right)$. The indicator makes the mixture red. The titration is carried out with $\mathrm{TBAH}^{6}$ ) as titrant in a one-phase medium and by means of the titration equipment (SBR2c, TTT1c, ABU1b, TTA4, PH 8604) from Radiometer, Copenhagen (see Fig. 1). Detailed instructions for operating the titration equipment can be found in the Radiometer manuals for the instruments.

The titration beaker is placed in the titration head (photo-cell chamber) of TTA4 (Fig. 2), and the sample is bubbled 1 to $2 \mathrm{~min}$. with $\mathrm{KOH}$-washed $\mathrm{N}_{2}$ under constant stirring. The gas inlet tube is then raised above the surface of the sample so that an atmosphere of nitrogen is created within the beaker ${ }^{i}$ ).

When all the controls of the equipment have been accurately adjusted, the titration proper will take from 2 to $6 \mathrm{~min}$. to complete (depending on the amount of frec fatty acids in the sample). The stirrer is constantly operated while titrant is added to ensure a uniform distribution, but this docs not have any noticcable effect on the efficiency of the photo-cell.

When the titration is completed, the titration beaker is rinsed twice with isopropanol, and it is then ready for the next measurement.

5) 1-(2-hydroxybenzene)-azo-2-naphthol (available from Radiometer, Copenhagen, as Indicator, type S 5203).

6) Tetrabutylammoniumhydroxide, E. Merck, AG, Darmstadt.

i) Tests where bubbling with $\mathrm{N}_{2}$ was omitted did not give reproducible results.

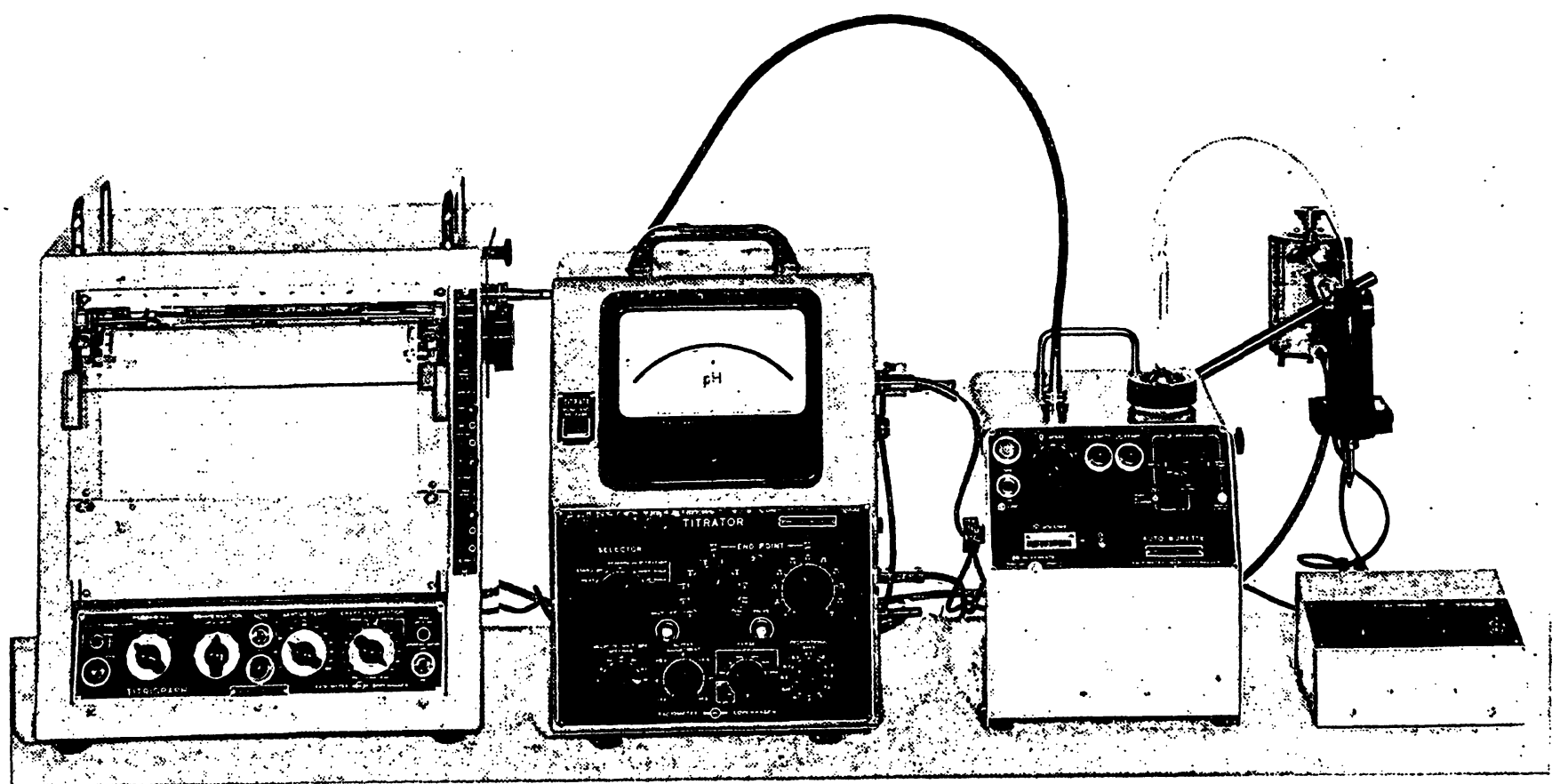

Fig. 1

The Radiometer equipment: Titrigraph, Titrator, Autoburette, Photo-cell chamber and Supply Unit 


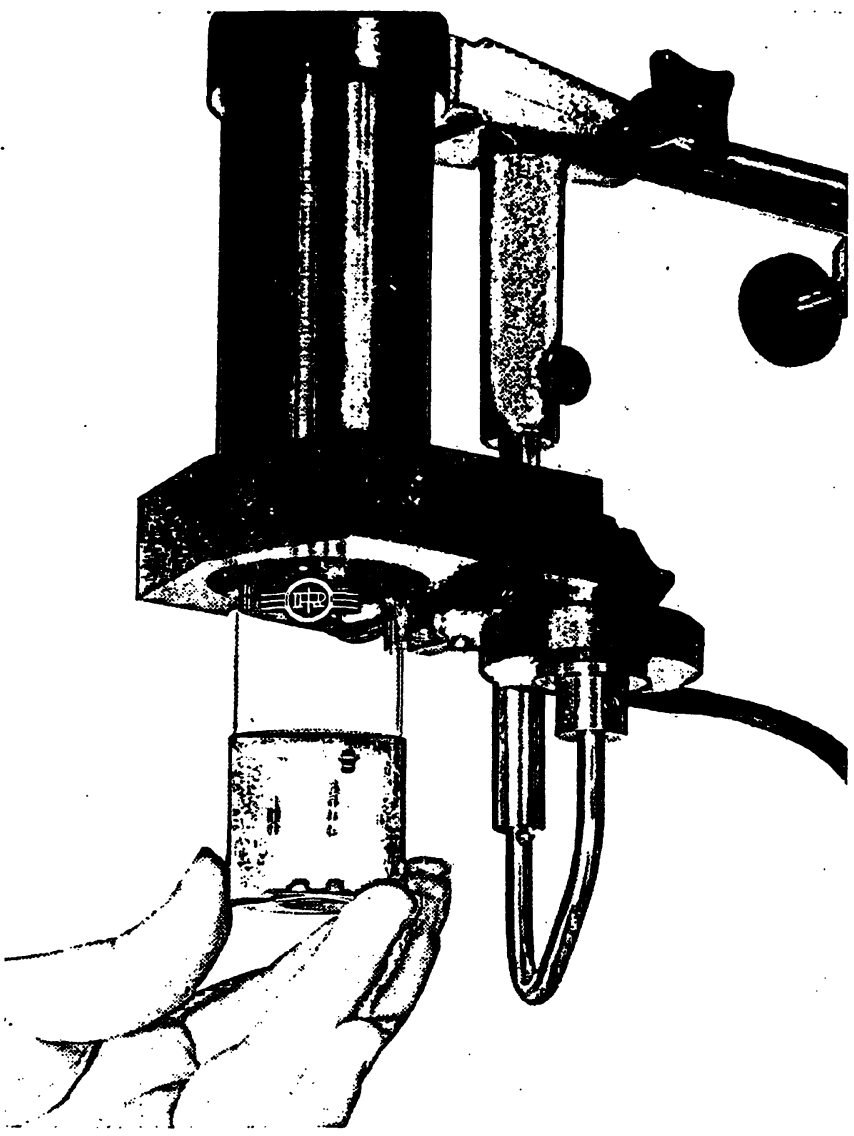

Fig. 2

The installation of the beaker in the photo-cell chamber

The course of the titration is recorded via a photo-cell. The intensity of light (from a built-in light source) traverses a standardized titration beaker containing the isopropanol-heptaneindicator test solution with its contents of dissolved free fatty acids; and is detected by a photo-cell connected to the Titrator TTT1c (Fig. 1). Immediately before the titration is performed, the light intensity, as measured by the photo-cell, is balanced against the zero setting of the titrator by means of the balance control of the Supply Unit (PHA804 - Fig. 1).

Once the set-up has been adjusted and the titration process is set going from the Titrator, the Auto-Burette (ABU1b - Fig. 1) commences delivery of titrant. When a change occurs in light intensity because of titrant addition, and the system therefore is caused to depart from the preset value, the Auto-Burette stops, and the combined compensation voltage and chart feed of the Recorder, SBR2c (see Fig. 1) is set in motion until the measuring value again corresponds to the original setting. When this compensation is completed, the Titrator stops the chart feed motor and starts the Auto-Burette again.

The titration process is an alternation between titrant delivery and compensation of the resultant change in light intensity. The control link between both functions is the Titrator in conjunction with the photo-cell.

When titrant is added, the pen of the Titrigraph is simultaneously started. During this phase of the alternating process, all horizontal portions of the curve are recorded (see Fig. 3). During the compensation phase, the pen is stationary, such that the forward movement of the chart causes the vertical portions of the curve to be traced. The titration curve thus produced is a stepped line consisting of horizontal and vertical portions (as seen, greatly exaggerated, in Fig. 3).

A line joining all points on this curve at which the recorder has only just compensated for the titrant increment and a new titrant increment is about to be delivered, is the true titration curve. The slope of the curve is dependent on the relationship between titrant increments and compensation of the resulting deviation. If only a slight colour change is produced, even though a large increment of titrant has been added, the tun of the curve will be practically horizontal. If the colour change is great, e. $g$. in the range bracketing the transition point of the indicator, then the corresponding compensation is equally great, and the curve produced will be steep.

The selected indicator does not change from red to blue before the free fatty acids have been titrated. The titration of fatty acids is completed at the point where the oblique part of the curve begins.

The volume of titrant needed to titrate the fatty acids can be found at the intersection of the extrapolated horizontal and oblique portions of the curve (see Fig. 4).

In order to determine the free fatty acid content in a sample, it is necessary to make standard measurements under identical conditions. $1.2 \mathrm{~mm}$ and $0.3 \mathrm{~mm}$ Solutions of palmitic acid are used as standards. These standards are prepared in exactly the same way as the plasma sample; thus, for the extraction process, $5 \mathrm{ml}$ ex-

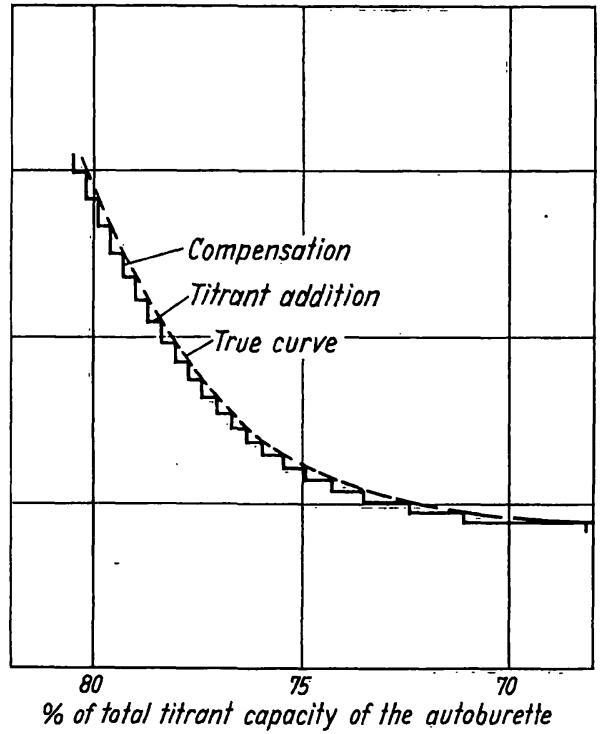

Fig. 3

The true titration curve and the titration curve like a stepped line as a function of titrant delivery and light intensity (explanation see text)

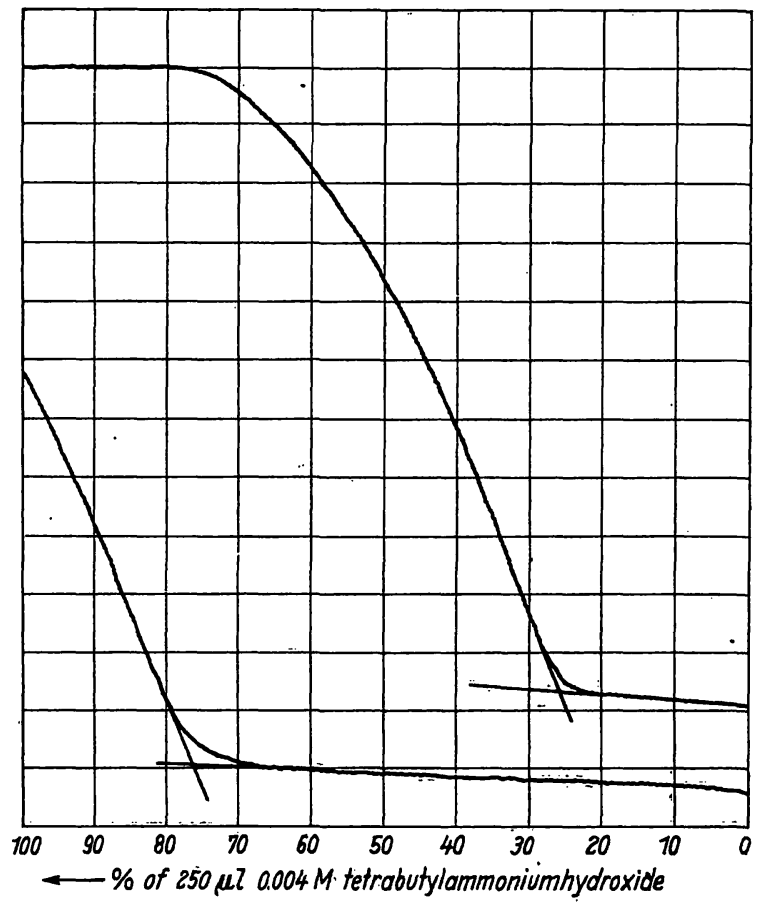

Fig. 4

Curve of standard titration. Determination of the transitionpoint by drawning 
traction solution and $1 \mathrm{~m} l$ standard $A$, or standard $B$, are added with a pipette. Since this $1 \mathrm{~m} /$ standard is a heptane solution $(1 \mathrm{~m} l$ plasma is an aqueous solution), $2 \mathrm{~m} l$ heptane and $4 \mathrm{ml}$ distilled water are then added instead of $3 \mathrm{~m} /$ heptane and $3 \mathrm{~m} /$ distilled water. This ensures that equal portions of isopropanol, heptane and water are contained in the standard sample as well as in the plasma.

A calculation of the content of free fetty acids in a sample in accordance with end-point and standard titrations is made by means of the following equation:

$\mathrm{x}=\frac{\ddot{[c}(\mathrm{m}-\mathrm{n})+\mathrm{a} \cdot \mathrm{n}-\mathrm{b} \cdot \mathrm{m}] 10^{8}}{\mathrm{a}-\mathrm{b}} \mu$ equiv. free fetty acids $/ \mathrm{ml}$

where

$\mathrm{a}=$ titrant consumption (in $\mathrm{m} l$ ) in 'Standard $\mathrm{A}^{\text {' titration }}$

$\mathrm{b}=$ titrant consumption (in $\mathrm{m} l$ ) in 'Standard B' titration

$c=$ titrant consumption (in $\mathrm{m} l$ ) in 'Sample' titration

$\mathrm{m}=$ molarity of 'Standard $\mathrm{A}$ '

$\mathrm{n}=$ molarity of 'Standard B'

\section{Results and Discussion}

Determination of palmitic acid solutions of specific concentrations

Solutions having different contents of palmitic acid were each washed once with $0.005 \mathrm{~N} \mathrm{H}_{2} \mathrm{SO}_{4}$ or once with $0.01 \mathrm{~N}_{2} \mathrm{SO}_{4}$ in three duplicate tests, and then determined (Fig. 5).

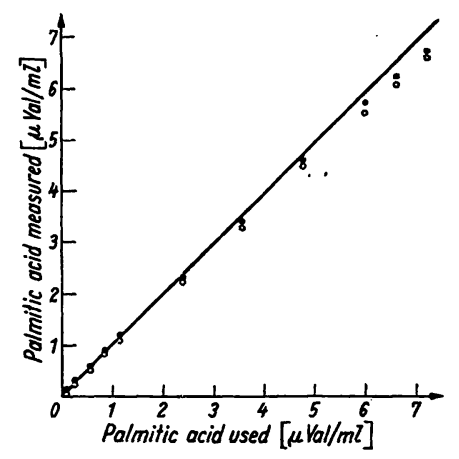

Fig. 5

Measured concentrations of palmitic acid in solutions, containing $0.0-7.25 \mu$ equiv. $/ \mathrm{ml}$

- Washing with $0.01 \mathrm{~N}_{2} \mathrm{SO}_{4}$

Below $0.30 \mu$ equiv. palmitic acid per $\mathrm{ml}$, as much as $3 \%$ more palmitic acid than actually used were detected. In the range from $0.30 \mu$ equiv. palmitic acid per ml to $2.40 \mu$ equiv. palmitic acid per ml. using palmitic acid per mleviation in measured quantity of the specified amount of palmitic acid was $\pm 1 \%$

amount of palmitic acid was $\pm 1 \%$
In the range from $2.40 \mu$ equiv. palmitic acid per $\mathrm{ml}$ to $4.80 \mu$ equiv. In the range from $2.40 \mu$ equiv. palmitic acid per ml to $4.80 \mu$ equiv. palmitic acid per miation between quantity used and quantity measured approached $-5 \%$

The error when using $0.005 \mathrm{~N} \mathrm{H}_{2} \mathrm{SO}_{4}$ was almost twice as great. Greatest accuracy was obtained with $0.01 \mathrm{~N}$ $\mathrm{H}_{2} \mathrm{SO}_{4}$ with concentrations of fatty acids lying between $0.30 \mu$ equiv. per $\mathrm{m} l$ and $2.40 \mu$ equiv. per $\mathrm{m} l$.

\section{Recovery}

a) To an albumin solution with a low free fatty acid content $(4 \mathrm{~g}$ albumin $/ 100 \mathrm{~m} l$ twice-distilled water) was added a measured quantity $(0.1 \mathrm{mMol})$ of palmitic acid. The palmitic acid was afterwards recovered with an error less than $4 \%$ (tab. 1,2).

\section{Reproducibility}

In a series of analyses performed under identical conditions, the difference between the individual values obtained was less than $\pm 1 \%$ (tab. 3 ).
Tab. 1

Recovery of palmitic acid in an albumin solution $(n=3)$

\begin{tabular}{cccc}
\hline $\begin{array}{c}\text { Albumin solution } \\
\text { content of free } \\
\text { fatty acids } \\
(\mu \text { equiv. } / \mathrm{m} l)\end{array}$ & $\begin{array}{c}\text { Palmitic acid } \\
\text { added } \\
(\mu \text { equiv. } / \mathrm{m} l)\end{array}$ & $\begin{array}{c}\text { Measured } \\
\text { quantity } \\
(\mu \text { equiv./ml) }\end{array}$ & $\begin{array}{c}\text { Difference } \\
(\mu \text { equiv./ml) }\end{array}$ \\
\hline 0.120 & 1.000 & 1.080 & -0.40 \\
\hline
\end{tabular}

Tab. 2

Recovery of palmitic acid, dissolved in heptane added to plasma

\begin{tabular}{cccc}
$\begin{array}{c}\text { Plasma content } \\
\text { of free fatty } \\
\text { acids }\end{array}$ & $\begin{array}{c}\text { Palmitic acid } \\
\text { added } \\
\text { ( } \mu \text { equiv./ml) }\end{array}$ & $\begin{array}{c}\text { Measured } \\
\text { quantity } \\
\text { ( } \mu \text { equiv./ml) }\end{array}$ & $\begin{array}{c}\text { Difference } \\
\text { ( } \mu \text { equiv./ml) }\end{array}$ \\
\hline 0.676 & 0.300 & 0.969 & -0.007 \\
0.530 & 0.300 & 0.844 & +0.014 \\
0.690 & 0.300 & 0.960 & -0.030 \\
0.676 & 0.600 & 1.283 & +0.007 \\
0.530 & 0.600 & 1.146 & +0.016 \\
0.690 & 0.600 & 1.250 & -0.040 \\
0.390 & 0.600 & 0.988 & -0.002 \\
\hline
\end{tabular}

Tab. 3

Reproducibility in a series of analyses of blood plasma

\begin{tabular}{cccccc}
\hline Sample no. & 1 & 2 & 3 & 4 & 5 \\
\hline $\begin{array}{c}\text { Test I free fatty acids } \\
\mu \text { equiv./m } l\end{array}$ & 0.690 & 0.120 & 0.828 & 1.374 & 0.659 \\
$\begin{array}{c}\text { Test II free fatty acids } \\
\quad \begin{array}{l}\text { equiv./ml } \\
\text { Test III free fatty acids } \\
\mu \text { equiv./ml }\end{array}\end{array}$ & 0.698 & 0.120 & 0.817 & 1.365 & 0.665 \\
\hline
\end{tabular}

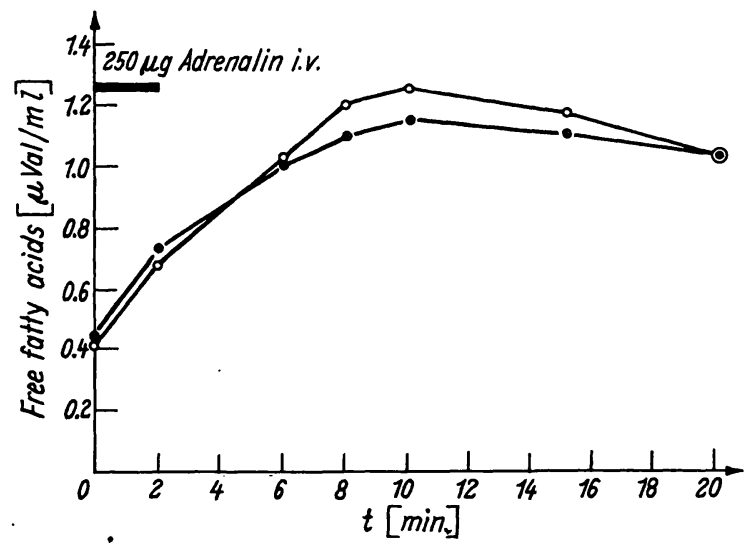

Fig. 6

The arteriovenous difference of free fatty acids after injection of $250 \mu \mathrm{g}$ of adrenaline

$\circ-\circ$ arterial, $\bullet-\bullet$ venous values

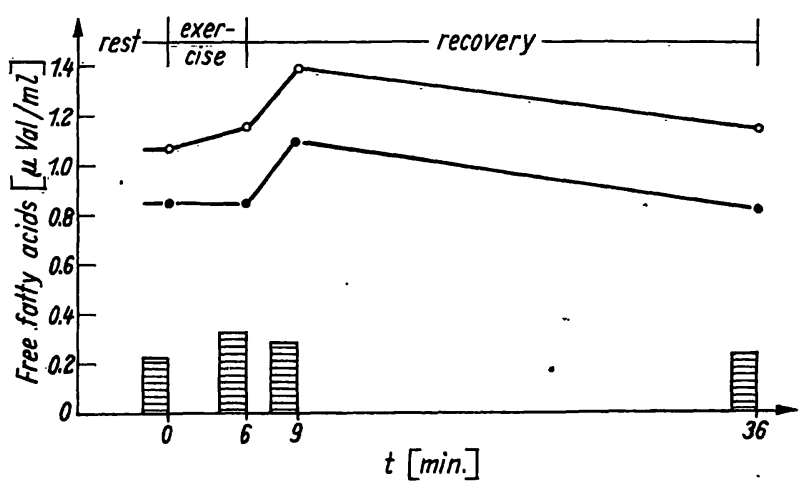

Fig. 7

Free fatty acids in arterial and coronary venous blood of patients $(n=15)$ with heart failure in rest and during exercise ○-० arterial, - - coronary venous values, Columns = arteriocoronary-venous difference 
Determination of free fatty acids in plasma under diverse conditions

1. Following an intravenous injection of $250 \mu \mathrm{g}$ adrenaline over a period of $2 \mathrm{~min}$., a steep increase in the free fatty acid content of both arterial and venous blood was observed within $10 \mathrm{~min}$. The arteriovenous difference, which before the injection of adrenaline is very small, increased to a maximum after $10 \mathrm{~min}$., and returned to the original value after $20 \mathrm{~min}$. The arterial blood was sampled from the $A$. bracbialis dextra, and the venous sample was obtained by inserting an approximately $20 \mathrm{~cm}$ long catheter deeply into the muscle tissue of the left forearm (Fig. 6).

2. Arterio-coronary-venous difference in patients suffering from cardiac insufficiency were subjected to extreme strain on a bicycle ergometer. As already reported for athletes who go in for top-strain sports $(8,9)$, the con- centration of free fatty acids in their blood is seen to increase during the physical exertions. The concentration of free fatty acids is at its greatest after 3 min. of maximum exertion. Obviously, the arterio-coronary-venous difference during maximum exertion becomes greater as a result of an increasing extraction of free fatty acids by the heart muscle (Fig. 7).

3. The determination of free fatty acids in the plasma of horses in rest and after a training of $20 \mathrm{~min}$. was made and the results are given in table 4 .

Tab. 4

Free fatty acids ( $\mu$ equiv. $/ \mathrm{ml}$ ) in the plasma of horses in rest and after training of $20 \mathrm{~min}$.

\begin{tabular}{llc}
\hline horses & rest & after exercise \\
\hline P. & 0.048 & 0.178 \\
D. & 0.117 & 0.176 \\
P. W. & 0.078 & 0.261 \\
R. & 0.048 & 0.245 \\
\hline
\end{tabular}

\title{
References
}

1. Dole, V. P., J. Clin. Invest. 35, 150 (1956). - 2. Gordon, R. S. jr., and A. Cherkes, J. Clin. Invest. 36, 810 (1957). - 3. Nelson, G. H., Amer. J. Obstetr. Gynec. 92, 202 (1965). 4. Kelley, T. F., Analytic. Chem. 37, 1078 (1965). - 5. Dole, V. P. and H. Meinertz, J. biol. Chemistry 235, 2595 (1960). 6. Trout, D. L., E. H. Estes, jr., and S. J. Friedberg, J. Lipid Res. 1, 199 (1960). - 7. LinNer, N., Automatic titration of free fatty, acids in plasma, ST 48, Radiometer, Copenhagen, Denmark. - 8. Fredrickson, D. S. and R. S. Gordon, Physiol. Rev. 38 , 585 (1958). - 9. Keul, J., E. Doll, H. Steim, H. Homburger, H. Kern and H. ReIndell, Pflügers Arch. Physiol. 282, 1 (1965). - 10. Keul, J., E. Dold, H. Sterm, H. Homburger, H. KerN and H. ReINDELL, Zsschr. Kreisl.forsch. 55, 190 (1966).

Doz. Dr. J. Keul

Medizinische Univ. Klinik 78 Freiburg

Hugstetterstr. 55

\section{Isolierung eines Xylose-haltigen Glykoproteids aus dem Erythrocyten-Stroma ${ }^{1}$ )}

\author{
Von H. WeICKER \\ Aus der Abteilung für Stoffwechselforschung (Leiter: Prof. Dr. H. Weicker) der Medizinischen Universitäts-Poliklinik \\ Heidelberg (Direktor: Prof. Dr. H. Plügge)
}

(Eingegangen am 27. März 1968)

\begin{abstract}
Aus dem Erythrocyten-Stroma von 25 Blutspenderkonserven, die nach den Blutgruppeneigenschäften $\mathrm{A}, \mathrm{B}, 0, \mathrm{MN}, \mathrm{Rh}$ und nach der Länge der Lagerungszeit der Konserven klassifiziert worden waren, wurden mit dem Phenol-Wasser-System nach der Methode von Westphal und Mitarbeitern, modifiziert von UHLENBRUCK und Mitarbeitern, zwei chemisch und serologisch unterschiedliche Glykoproteide dargestellt.

Das Glykoproteid (W), isoliert aus der Wasser-Phase, enthält MN-Antigen und Virus-Rezeptoren. Wir konnten im wesentlichen die in der Literatur beschriebenen chemischen Eigenschaften dieser Substanz bestätigen, fanden jedoch, daß die Ausbeute von den Blutgruppeneigenschaften und der Lagerungszeit der Konserven abhängig war. Bei 0- und AB-Erythrocyten war die Ausbeute am höchsten und zeigte auch die geringste Beeinflussung durch längere Lagerungszeit. Entgegen den Befunden anderer Autoren fanden wir bei den $M$-Erythrocyten den höchsten Neuraminsäuregehalt, der bei $22-24 \%$ lag und zu $85-90 \%$ enzymatisch abspaltbar war. Die Kohlenhydrat-Komponenten des Glykoproteids (W) waren Galaktose, Mannose, Fucose in einer Verteilung von 4:2:1 sowie Galaktosamin, Glucosamin in einer Verteilung von 5:3. Der Gesamtkohlenhydratgehalt betrug 37-41\%. Insgesamt waren 16 Aminosäuren chromatographisch zu identifizieren.

Das bis jetzt noch nicht beschriebene Glykoproteid (P) wurde aus der Phenol-Phase nach Entfernung der Lipide isoliert und enthielt Xylose in einer Konzentration von 3-3,5\%. Es hatte einen geringeren Neuraminsäuregehalt (8-10\%) als das Glykoproteid (W). Die Neuraminsäure war nur zu 60-70\% abspaltbar. Seine Kohlenhydrat-Komponenten waren Galaktose, Mannose, Fucose, Xylose, Glucose in einer Verteilung von 4:2:1:3:1 und Galaktosamin, Glucosamin in einer Verteilung von 3:2 bei einem Gesamtkohlenhydratgehalt von $20-25 \%$. Die Aminosäure-Zusammensetzung zeigte keine wesentlichen Unterschiede zu dem Glykoproteid (W). Das Glykoproteid (P) besaß keine $\mathrm{MN}$-Antigen-Eigenschaften und hemmte die Virus-Hämagglutination nur geringfügig.
\end{abstract}

1) Mit Unterstützung der Deutschen Forschungsgemeinschaft. 